\title{
Yield Estimation of Rice Crop at Pre-Harvest Stage Using Regression Based Statistical Model for Arwal District, Bihar, India
}

\author{
Ravi Ranjan Kumar*, S.N. Singh, Kiran Kumari and Bhola Nath \\ Department of Statistics, Mathematics and Computer Application \\ Bihar Agricultural University, Sabour, Bhagalpur, Bihar - 813210, India \\ *Corresponding author:
}

\section{Keywords \\ Yield estimation, Bio-metrical, Characters of rice, Farmer's appraisal, Regression technique}

\section{Article Info}

Accepted:

22 July 2019

Available Online:

10 August 2019

\section{A B S T R A C T}

The estimation of crop yield before harvest helps in different policy making in an order for storage, distribution, marketing, pricing, import-export etc. Crop productions depend on several factors such as weather factors, plant characters and agricultural inputs. The present study was carried out to develop the appropriate statistical model for estimation of rice yield before harvest in the year 2018-19. This research was done on plant biometrical characters along with farmer's appraisal. Sample survey was done on farmer's field through multistage stratified random sampling method and recorded fourteen parameters such as $X_{1}$ (Number of irrigation), $X_{2}$ (Average plant population), $X_{3}$ (Average plant height), $X_{4}$ (Average number of effective tillers), $X_{5}$ (Average length of panicle), $X_{6}$ (Average length of flag leaf), $X_{7}$ (Average width of flag leaf), $X_{8}$ (Average number of filled grain), $X_{9}$ (Damage due to pest and disease infestations), $X_{10}$ (Applied nitrogen), $X_{11}$ (Applied phosphorus), $\mathrm{X}_{12}$ (Applied potassium), $\mathrm{X}_{13}$ (Average plant condition) and $\mathrm{Y}$ (Yield). By the help of step-wise regression technique to select thirteen models on the basis of minimum BIC value and then after best models were selected on the basis of minimum AIC value. After regression analysis, one best fitted model was selected on the basis of some important statistics such as RMSE, ${ }^{2}$, Adj.R ${ }^{2}, C . V$, Residual and Cook's D statistic. However, $10 \%$ observations were kept for model validation test purpose. Model $2\left(\bar{Y}=27.07355-1.69966 X_{1}+0.25058 X_{2}+0.24110 X_{4}+1.28741 \mathrm{X}_{5}-0.45193 \mathrm{X}_{6}+\right.$ $1.17152 \mathrm{X}_{13}$ ) had minimum value of coefficient of variation, residual, and student residual which were $6.36430,0.0000$, and -0.0756 respectively. Value of Adj. $R^{2}(0.8197)$ which indicated the better to fit of variables in the model. After model validation test, the lowest value of MAPE (1.18 - 5.48) were indicated the good precision for model-2. Thus the estimated rice yield in Arwal district is about 33.28 q/ ha for the year 2018-19.

\section{Introduction}

Rice (Oryza sativa) is one of the most important cereal crops in India. It is the staple food for millions in the world and feeds more than half of humanity on a daily basis and provides a major and most stable source of income. It is cultivated on 42.96 million hectares of land and producing 158.75 metric tons rice with productivity of 3.95 tons/hectare (F.A.O STAT, 2016). Bihar is also an important rice growing state in the 
country. Rice is grown on 3.34 million hectares of land and producing 8.24 metric tons with productivity of 2.46 tons/hectare (Directorate of Economics and Statistics, GoB., 2016-17). However, after using the available technology and proper demonstration, it is possible to increase the productivity. The estimation of crop yield before harvest helps in different policy making in an order for storage, distribution, marketing, pricing, import-export etc. (Vogel and Bange, 1999). The estimation of crop yields before harvest are considered mainly as an aid to conjecture the final production and therefore, sufficient attention needs to be paid towards their improvement. That is not only deals with developing model but also considered the accuracy of the model.Thus reliable and timely forecasting of crop yields before harvest are very important.

Different kinds of organisation are involved in developing methodologies before harvest by using various approaches such as plant biometrical characteristics, weather variables, agricultural inputs etc. These approaches can be used individually or in combination. The plant morphological characters like number of plant per plot, number of tillers per plant, numbers of grain per panicle etc. may affect directly and other characters like plant height, leaf area, panicle length etc. may affect indirectly the yield of crop. Chemical fertilizers are helps in growth and development of the crop and incidence of disease and pest infestations are also affected the growth, development and the crop yield.

Nath et al., (2018) worked on pre-harvest forecasting for rice yield through Bayesian approach. Deep et al., (2018), Kumar et al., (2017) worked yield estimation of rice crop by using of biometrical characters along with farmer's appraisal and develop forecasting model. Pandey et al., (2013) suggested models for forecasting rice yield in eastern
U.P based on weather variables and weather indices (1989-90 to 2009-10). They used stepwise regression to screen out the weather variables and estimated the model parameters through multiple regression approach.

\section{Materials and Methods}

The present investigation was carried out by following steps.

\section{Sampling technique:}

By using multi stage stratified random sampling method, samples were selected in different villages of blocks. In First stages blocks were selected purposively, then in second stage panchayats were selected randomly. In Third stage villages were selected and last in fourth stage two plots of each farmer were selected by simple random system.Total Sixty samples were selected in Arwal district.

\section{Recognition of measurable as well as non- measurable characters}

The characters like number of plant per plot, number of tillers per plant, numbers of grain per panicle, plant height, leaf area, panicle length, chemical fertilizers, disease incidence and pests etc. were taken for the yield estimation of rice crop in Arwal district of Bihar.

\section{Data collection and development of regression model}

The primary data such as plant population, plant height, number of effective tillers, length of panicle, length of flag leaf, width of flag leaf, number of filled grain per panicle, level of irrigation, applied nitrogen, phosphorus, potassium, disease and pest infestation were recorded by self-observations and by personal interviews. By the self- 
observations, data were recorded from the farmer's field in the area of one square meter.

\section{Identification of appropriate subset for regression study}

With the help of SAS v 9.3, regression analysis was carried out of selected best five model. On the basis of $\mathrm{R}^{2}$, Adj. $\mathrm{R}^{2}$, RMSE, Residual analysis and Cook's D criteria best sub model has to be chosen.

\section{Application of statistical tools to test the validity of regression models}

For validity of regression models, following major assumptions was considered:

The relationship between the dependent variable(Y) and independent variables (X's) should be linear in nature

The error terms which are assumed to be normally and independently distributed will zero mean and constant variance.

\section{Results and Discussion}

All the parameters were used for the development of different models. By using software SAS JMP v 13.0, eight thousand one hundred ninety-two different combinations of regression models were developed. On the basis of minimum BIC value, thirteen best models were highlighted for each term. Out of these thirteen highlighted models, five best models were selected based on the least AIC value which were given in the Table 2 .

The all possible statistical analysis was carried out to compute for 54 observations through software SAS v 9.3. From the table 2. The model-1 had four explanatory variables and model-3 had five explanatory variables. For $3^{\text {rd }}$ model the value of $\mathrm{R}^{2}$ was higher than from the $1^{\text {th }}$ model. That was increment of
0.0074 , which was less than 0.01 . The value of Adj. $\mathrm{R}^{2}$ for $3^{\text {rd }}$ model there was increment of 0.0042 which was also very less which showed that there was no need of extra $\mathrm{X}_{4}$ regressor was for the model- 3. From the model-2, which had six explanatory variables whose value of $\mathrm{R}^{2}$ was 0.8401 . In which there was increment of 0.0084 from the $3^{\text {rd }}$ model and increment of 0.0158 from the $1^{\text {st }}$ model. The value of Adj. $\mathrm{R}^{2}$ for the $2^{\text {nd }}$ model was 0.8187 that was more than 0.0056 and 0.0098 from the $3^{\text {rd }}$ and $4^{\text {th }}$ model respectively which had higher increment in value as compare to other models. So extra $X_{2}$ and $X_{4}$ regressors were sufficient for the model-2. The model-4 had seven sub set regression model, $0.8449 \mathrm{R}^{2}$ values that was increment of 0.0048 from the $2^{\text {nd }}$ model. It was not sufficient in the $4^{\text {th }}$ model. The value of Adj. $\mathrm{R}^{2}$ in the $4^{\text {th }}$ model was 0.8212 which had 0.0025 increments as compare the $2^{\text {st }}$ model that was very less value, so extra $X_{12}$ variable was not significant for the model-4. From the model5 , which had eight regressors and its value $\mathrm{R}^{2}$ was 0.8495 and Adj. $\mathrm{R}^{2}$ value was 0.8228 . Both the values had very less precision of results as compare to the model-3 and 4 . Hence there was no need to include regressors $\mathrm{X}_{3}$ and $\mathrm{X}_{9}$ in the model-5.We may concluded that the Model-2( $\bar{Y}=27.07355-1.69966 X_{1}+$ $0.25058 \mathrm{X}_{2}+0.24110 \mathrm{X}_{4}+1.28741 \mathrm{X}_{5}-$ $\left.0.45193 \mathrm{X}_{6}+1.17152 \mathrm{X}_{13}\right)$ was best to fit for the estimation of rice yield in Arwal district of Bihar. It had six regressors viz. X1, X2, X4, X5, X6 and X13 whose most parameters were significant at $1 \%$ level of significance along with intercept. The increment of Adj. $\mathrm{R}^{2}$ value was higher as compared to other models. All observations of residuals were lesser than other models showed that the best fitted model for the predicting yield. The value for coefficient of variation, residual, and student residual for model-2 were $6.36430,0.0000$, and -0.0756 respectively. Which were lower than other model. The analysis of variance (ANOVA) for this model 
showed that the $\mathrm{F}$ value was highly significant at $1 \%$ level of significance. Graph of the model-2 (fig-3) showed that low value of residual for most of the observations showed the good accuracy for the model. Variance of inflation were less than two which showed that there was no any sign of multicollinearity for the parameters.

The set of six observations which were given in Table 4, that corresponds to the variables have been included in the model. These observations were not used in model building. For each set of observation, the estimated deviation and mean absolute percentage error of prediction has been presented.After model validation, it was found that the value of percentage error as this model had less than 5.48 and 2.5600 average value. That indicated that model was used with good accuracy to estimate rice yield. So it was used for estimation of rice yield in Arwal district of Bihar for the year 2018-19. After using the model-2, the estimated yield of rice was found be about 33.28 q/ ha for the year 201819. This is totally based on biometrical characters and farmer's appraisal.

Table.1 List of measurable and non-measurable characters

\begin{tabular}{|c|c|c|c|c|}
\hline S.N. & Variables & $\begin{array}{c}\text { Code of } \\
\text { variables }\end{array}$ & $\begin{array}{c}\text { Unit of } \\
\text { measureme } \\
\text { nt }\end{array}$ & $\begin{array}{l}\text { Types of } \\
\text { characters }\end{array}$ \\
\hline 1. & Yield & $\mathrm{Y}$ & $\mathrm{q} / \mathrm{ha}$ & Measurable \\
\hline 2. & Number of irrigation & $\mathrm{X}_{1}$ & numbers & Measurable \\
\hline 3. & $\begin{array}{c}\text { Average plant } \\
\text { population }\end{array}$ & $\mathrm{X}_{2}$ & per $\mathrm{m}^{2}$ & Measurable \\
\hline 4. & Average plant height & $\mathrm{X}_{3}$ & $\mathrm{~cm}$ & Measurable \\
\hline 5. & $\begin{array}{l}\text { Average number of } \\
\text { effective tillers }\end{array}$ & $\mathrm{X}_{4}$ & per $\mathrm{m}^{2}$ & Measurable \\
\hline 6. & $\begin{array}{l}\text { Average length of } \\
\text { panicle }\end{array}$ & $\mathrm{X}_{5}$ & $\mathrm{~cm}$ & Measurable \\
\hline 7. & $\begin{array}{l}\text { Average length of flag } \\
\text { leaf }\end{array}$ & $\mathrm{X}_{6}$ & $\mathrm{~cm}$ & Measurable \\
\hline 8. & $\begin{array}{l}\text { Average width of flag } \\
\text { leaf }\end{array}$ & $\mathrm{X}_{7}$ & $\mathrm{~cm}$ & Measurable \\
\hline 9. & $\begin{array}{l}\text { Average number of } \\
\text { filled grain }\end{array}$ & $\mathrm{X}_{8}$ & numbers & Measurable \\
\hline 10. & $\begin{array}{l}\text { Damage due to pest } \\
\text { and disease infestations }\end{array}$ & $\mathrm{X}_{9}$ & percent & Measurable \\
\hline 11. & Applied nitrogen & $\mathrm{X}_{10}$ & $\mathrm{~kg} / \mathrm{ha}$ & Measurable \\
\hline 12. & Applied phosphorus & $\mathrm{X}_{11}$ & $\mathrm{~kg} / \mathrm{ha}$ & Measurable \\
\hline 13. & Applied potassium & $\mathrm{X}_{12}$ & $\mathrm{~kg} / \mathrm{ha}$ & Measurable \\
\hline 14. & $\begin{array}{l}\text { Average plant } \\
\text { condition }\end{array}$ & $\mathrm{X}_{13}$ & eye estimate & $\begin{array}{c}\text { Non- } \\
\text { measurable }\end{array}$ \\
\hline
\end{tabular}


Table.2 Five best models for regression analysis

\begin{tabular}{|c|c|c|l|c|c|c|}
\hline S.N. & Model & Number & R.Square & Adj.R & RMSE & AIC \\
\hline $\mathbf{1}$ & $\mathrm{X}_{1}, \mathrm{X}_{5}, \mathrm{X}_{6}, \mathrm{X}_{13}$ & 4 & 0.8243 & 0.8099 & 2.6091 & 265.359 \\
\hline $\mathbf{2}$ & $\mathrm{X}_{1}, \mathrm{X}_{2}, \mathrm{X}_{4}, \mathrm{X}_{5}, \mathrm{X}_{6}, \mathrm{X}_{13}$ & 6 & 0.8401 & 0.8197 & 2.5413 & 265.677 \\
\hline $\mathbf{3}$ & $\mathrm{X}_{1}, \mathrm{X}_{4}, \mathrm{X}_{5}, \mathrm{X}_{6}, \mathrm{X}_{13}$ & 5 & 0.8317 & 0.8141 & 2.5802 & 265.691 \\
\hline $\mathbf{4}$ & $\mathrm{X}_{1}, \mathrm{X}_{2}, \mathrm{X}_{4}, \mathrm{X}_{5}, \mathrm{X}_{6}, \mathrm{X}_{10}, \mathrm{X}_{13}$ & 7 & 0.8449 & 0.8212 & 2.5303 & 266.94 \\
\hline $\mathbf{5}$ & $\mathrm{X}_{1}, \mathrm{X}_{2}, \mathrm{X}_{3}, \mathrm{X}_{4}, \mathrm{X}_{5}, \mathrm{X}_{6}, \mathrm{X}_{9}, \mathrm{X}_{13}$ & 8 & 0.8495 & 0.8228 & 2.5195 & 268.314 \\
\hline
\end{tabular}

Table.3 Parameter estimates of $2^{\text {nd }}$ model after regression analysis

\begin{tabular}{|c|c|c|c|c|c|c|}
\hline Variable & $\mathbf{D . F}$ & $\begin{array}{c}\text { Parameter } \\
\text { Estimate }\end{array}$ & $\begin{array}{c}\text { Standard } \\
\text { Error }\end{array}$ & $\mathbf{t}$ Value & Pr $>|\mathbf{t}|$ & $\begin{array}{c}\text { Variance } \\
\text { Inflation }\end{array}$ \\
\hline Intercept & 1 & 27.07355 & 8.49181 & 3.19 & $0.00^{* *}$ & 0 \\
\hline $\mathbf{X}_{\mathbf{1}}$ & 1 & -1.69966 & 0.13203 & -12.87 & $0.00^{* *}$ & 1.11663 \\
\hline $\mathbf{X}_{\mathbf{2}}$ & 1 & 0.25058 & 0.15903 & 1.58 & 0.12 & 1.04655 \\
\hline $\mathbf{X}_{\mathbf{4}}$ & 1 & 0.24110 & 0.15082 & 1.60 & 0.11 & 1.01870 \\
\hline $\mathbf{X}_{\mathbf{5}}$ & 1 & 1.28741 & 0.29453 & 4.37 & $0.00^{* *}$ & 1.07605 \\
\hline $\mathbf{X}_{\mathbf{6}}$ & 1 & -0.45193 & 0.13613 & -3.32 & $0.00^{* *}$ & 1.14886 \\
\hline $\mathbf{X}_{\mathbf{1 3}}$ & 1 & 1.17152 & 0.42964 & 2.73 & $0.00^{* *}$ & 1.06339 \\
\hline & & ANOVA & & & \\
\hline Source & DF & Sum of & Mean Sum & $\mathbf{F}$ & Pr > F \\
& & Squares & $\begin{array}{c}\text { of } \\
\text { Value }\end{array}$ & \\
\hline Model & 6 & 1594.83501 & 265.80583 & 41.16 & $0.00^{* *}$ \\
\hline \multicolumn{2}{|c|}{ Error } & 47 & 303.53318 & 6.45815 & & \\
\hline Corrected Total & 53 & 1898.36819 & & & \\
\hline
\end{tabular}

Note:- ** (1\% level of significance) 
Table.4 Residual analysis of 54 observations used in $2^{\text {nd }}$ model

\begin{tabular}{|c|c|c|c|c|c|c|c|}
\hline $\begin{array}{c}\text { Obs } \\
.\end{array}$ & $\begin{array}{c}\text { Dependen } \\
\mathbf{t} \\
\text { Variable }\end{array}$ & $\begin{array}{c}\text { Predicte } \\
\text { d } \\
\text { Value }\end{array}$ & $\begin{array}{c}\text { Std Error of } \\
\text { Mean Predicte } \\
\text { d }\end{array}$ & Residual & $\begin{array}{c}\text { Std Erro } \\
\text { r } \\
\text { Residual }\end{array}$ & $\begin{array}{l}\text { Student } \\
\text { Residual }\end{array}$ & $\begin{array}{c}\text { Cook's } \\
\text { D }\end{array}$ \\
\hline 1 & 42.0000 & 43.4394 & 1.1264 & -1.4394 & 2.278 & -0.632 & 0.014 \\
\hline 2 & 40.0000 & 40.4822 & 0.8362 & -0.4822 & 2.400 & -0.201 & 0.001 \\
\hline 3 & 44.5000 & 46.5284 & 0.7599 & -2.0284 & 2.425 & -0.836 & 0.010 \\
\hline 4 & 42.2500 & 40.8277 & 0.9412 & 1.4223 & 2.361 & 0.603 & 0.008 \\
\hline 5 & 45.7500 & 49.2314 & 0.9217 & -3.4814 & 2.368 & -1.470 & 0.047 \\
\hline 6 & 43.6600 & 46.6864 & 0.8635 & -3.0264 & 2.390 & -1.266 & 0.030 \\
\hline 7 & 44.6400 & 43.2961 & 0.7291 & 1.3439 & 2.434 & 0.552 & 0.004 \\
\hline 8 & 45.5000 & 43.3489 & 1.1980 & 2.1511 & 2.241 & 0.960 & 0.038 \\
\hline 9 & 44.7000 & 44.9995 & 0.5815 & -0.2995 & 2.474 & -0.121 & 0.000 \\
\hline 10 & 46.4000 & 48.4227 & 0.8432 & -2.0227 & 2.397 & -0.844 & 0.013 \\
\hline 11 & 42.0000 & 41.3669 & 0.7971 & 0.6331 & 2.413 & 0.262 & 0.001 \\
\hline 12 & 43.0000 & 41.1758 & 0.7986 & 1.8242 & 2.413 & 0.756 & 0.009 \\
\hline 13 & 46.7500 & 40.3434 & 0.9242 & 6.4066 & 2.367 & 2.706 & 0.159 \\
\hline 14 & 41.5100 & 40.3956 & 0.9945 & 1.1144 & 2.339 & 0.477 & 0.006 \\
\hline 15 & 34.4000 & 30.4485 & 1.0935 & 3.9515 & 2.294 & 1.723 & 0.096 \\
\hline 16 & 31.3500 & 34.8525 & 0.8971 & -3.5025 & 2.378 & -1.473 & 0.044 \\
\hline 17 & 47.0200 & 46.3339 & 0.8205 & 0.6861 & 2.405 & 0.285 & 0.001 \\
\hline 18 & 44.0000 & 45.2479 & 0.8686 & -1.2479 & 2.388 & -0.523 & 0.005 \\
\hline 19 & 34.0000 & 33.2203 & 0.8005 & 0.7797 & 2.412 & 0.323 & 0.002 \\
\hline 20 & 35.2000 & 32.8777 & 0.7018 & 2.3223 & 2.442 & 0.951 & 0.011 \\
\hline 21 & 44.0000 & 45.1228 & 0.6051 & -1.1228 & 2.468 & -0.455 & 0.002 \\
\hline 22 & 46.2400 & 45.2190 & 1.0910 & 1.0210 & 2.295 & 0.445 & 0.006 \\
\hline 23 & 39.4000 & 40.4533 & 1.6157 & -1.0533 & 1.962 & -0.537 & 0.028 \\
\hline 24 & 29.6000 & 31.0823 & 0.7525 & -1.4823 & 2.427 & -0.611 & 0.005 \\
\hline 25 & 43.7000 & 42.2871 & 1.1441 & 1.4129 & 2.269 & 0.623 & 0.014 \\
\hline 26 & 40.0000 & 41.1482 & 0.6896 & -1.1482 & 2.446 & -0.469 & 0.003 \\
\hline
\end{tabular}




\begin{tabular}{|l|l|l|l|l|l|l|l|}
\hline $\mathbf{2 7}$ & 46.0000 & 46.4654 & 1.5684 & -0.4654 & 2.000 & -0.233 & 0.005 \\
\hline $\mathbf{2 8}$ & 48.3300 & 44.8749 & 0.6973 & 3.4551 & 2.444 & 1.414 & 0.023 \\
\hline $\mathbf{2 9}$ & 45.0000 & 39.3926 & 0.4502 & 5.6074 & 2.501 & 2.242 & 0.023 \\
\hline $\mathbf{3 0}$ & 48.1400 & 45.5058 & 0.9597 & 2.6342 & 2.353 & 1.119 & 0.030 \\
\hline $\mathbf{3 1}$ & 44.6600 & 43.4414 & 1.0155 & 1.2186 & 2.330 & 0.523 & 0.007 \\
\hline $\mathbf{3 2}$ & 40.3300 & 40.3102 & 0.9939 & 0.0198 & 2.339 & 0.00846 & 0.000 \\
\hline $\mathbf{3 3}$ & 45.9400 & 47.7767 & 0.9833 & -1.8367 & 2.343 & -0.784 & 0.015 \\
\hline $\mathbf{3 4}$ & 44.8200 & 42.9986 & 0.6952 & 1.8214 & 2.444 & 0.745 & 0.006 \\
\hline $\mathbf{3 5}$ & 41.2500 & 42.7543 & 0.9436 & -1.5043 & 2.360 & -0.638 & 0.009 \\
\hline $\mathbf{3 6}$ & 44.0000 & 41.3742 & 0.6626 & 2.6258 & 2.453 & 1.070 & 0.012 \\
\hline $\mathbf{3 7}$ & 34.0000 & 36.3670 & 0.9061 & -2.3670 & 2.374 & -0.997 & 0.021 \\
\hline $\mathbf{3 8}$ & 29.1600 & 33.5334 & 0.6828 & -4.3734 & 2.448 & -1.787 & 0.035 \\
\hline $\mathbf{3 9}$ & 31.6600 & 36.9424 & 0.8480 & -5.2824 & 2.396 & -2.205 & 0.087 \\
\hline $\mathbf{4 0}$ & 30.0000 & 31.6787 & 0.9290 & -1.6787 & 2.365 & -0.710 & 0.011 \\
\hline $\mathbf{4 1}$ & 42.0000 & 43.2402 & 0.6935 & -1.2402 & 2.445 & -0.507 & 0.003 \\
\hline $\mathbf{4 2}$ & 43.0000 & 43.4860 & 1.1801 & -0.4860 & 2.251 & -0.216 & 0.002 \\
\hline $\mathbf{4 3}$ & 29.0000 & 29.9153 & 1.1924 & -0.9153 & 2.244 & -0.408 & 0.007 \\
\hline $\mathbf{4 4}$ & 25.0000 & 25.9059 & 1.0531 & -0.9059 & 2.313 & -0.392 & 0.005 \\
\hline $\mathbf{4 5}$ & 30.0000 & 31.8661 & 0.6840 & -1.8661 & 2.447 & -0.762 & 0.006 \\
\hline $\mathbf{4 6}$ & 36.0000 & 34.2859 & 0.8792 & 1.7141 & 2.384 & 0.719 & 0.010 \\
\hline $\mathbf{4 7}$ & 37.3300 & 37.1080 & 0.9918 & 0.2220 & 2.340 & 0.0949 & 0.000 \\
\hline $\mathbf{4 8}$ & 43.2800 & 41.0747 & 0.6733 & 2.2053 & 2.450 & 0.900 & 0.009 \\
\hline $\mathbf{4 9}$ & 37.3300 & 36.5335 & 1.2133 & 0.7965 & 2.233 & 0.357 & 0.005 \\
\hline $\mathbf{5 0}$ & 37.0000 & 32.6508 & 0.8588 & 4.3492 & 2.392 & 1.818 & 0.061 \\
\hline $\mathbf{5 1}$ & 33.3300 & 36.2254 & 0.9486 & -2.8954 & 2.358 & -1.228 & 0.035 \\
\hline $\mathbf{5 2}$ & 39.6600 & 39.6944 & 0.6335 & -0.0344 & 2.461 & -0.0140 & 0.000 \\
\hline $\mathbf{5 3}$ & 35.1200 & 36.9975 & 0.6107 & -1.8775 & 2.467 & -0.761 & 0.005 \\
\hline $\mathbf{5 4}$ & 33.3300 & 35.0028 & 0.5149 & -1.6728 & 2.489 & -0.672 & 0.003 \\
\hline
\end{tabular}


Table.4 Estimating error for the six set of observations which are not included in model building $\left(2^{\text {nd }}\right.$ model $)$

\begin{tabular}{|c|c|c|c|c|c|c|c|c|c|c|}
\hline S.N. & $\mathbf{X}_{1}$ & $\mathbf{X}_{2}$ & $\mathbf{X}_{4}$ & $X_{5}$ & $X_{6}$ & $\mathbf{X}_{13}$ & $\mathbf{Y}$ & $\widehat{\mathbf{Y}}$ & $\hat{e}_{i}=Y-\widehat{Y}$ & $M A P E=\frac{\left|\hat{e}_{i}\right|}{\widetilde{Y}}$ \\
\hline 1. & 12 & 19 & 16 & 23.6 & 41.2 & 4 & 30 & 31.74 & -1.74 & 5.48 \\
\hline 2. & 12 & 22 & 13 & 20.2 & 39 & 3 & 28 & 27.21 & 0.79 & 2.90 \\
\hline 3. & 13 & 27 & 15 & 22.8 & 38.5 & 4 & 31.5 & 31.99 & -0.49 & 1.53 \\
\hline 4. & 13 & 26 & 17 & 23.8 & 41.2 & 5 & 32.5 & 33.47 & -0.97 & 2.89 \\
\hline 5. & 10 & 26 & 15 & 23.4 & 38.5 & 5 & 39.25 & 38.79 & 0.46 & 1.18 \\
\hline 6. & 10 & 23 & 17 & 22.9 & 39 & 4 & 37 & 36.48 & 0.52 & 1.42 \\
\hline
\end{tabular}

Fig.1 Diagnostic fit for dependent variable (Y)

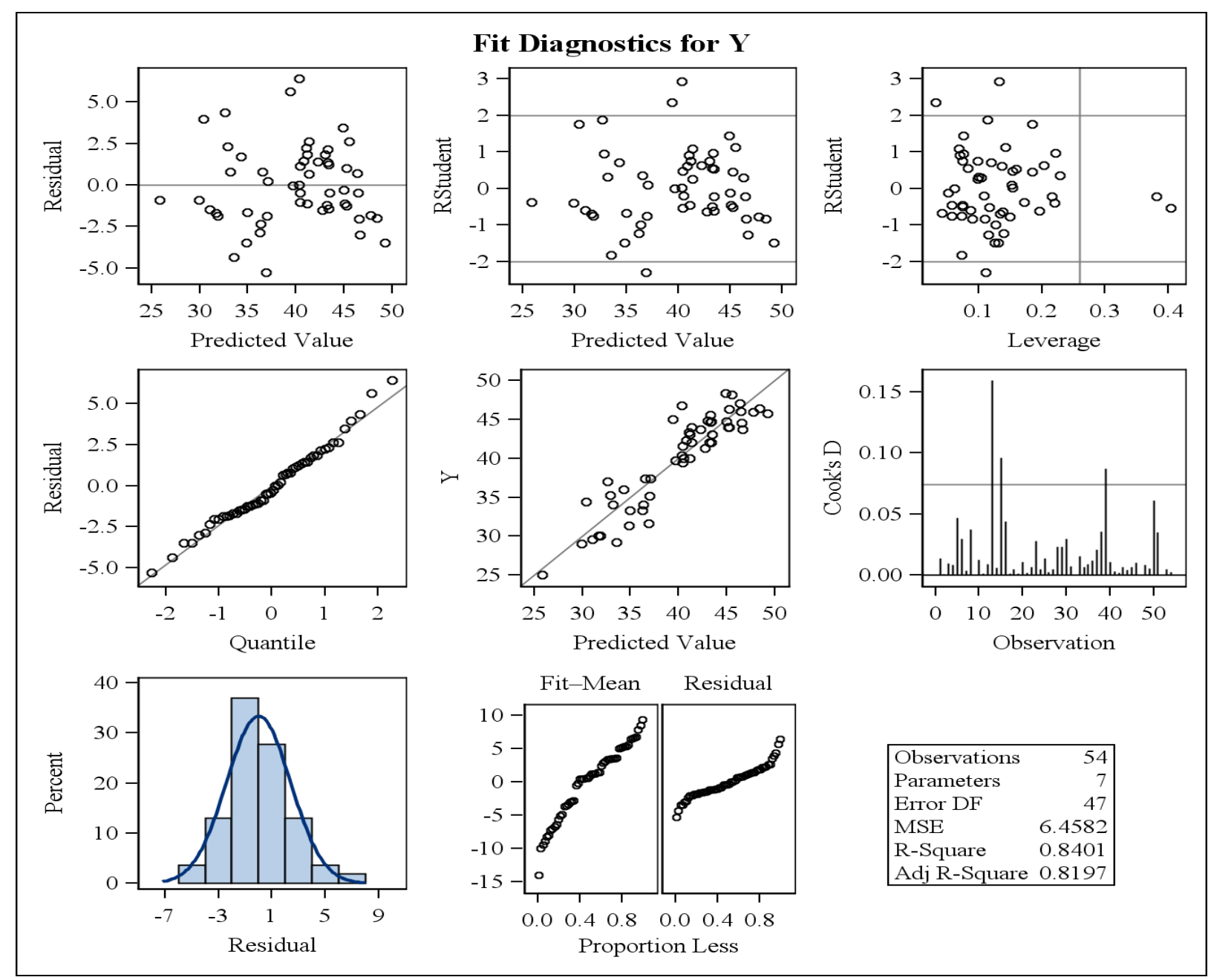


Fig.3 Graph shows the plotting between actual yield and predicted yield

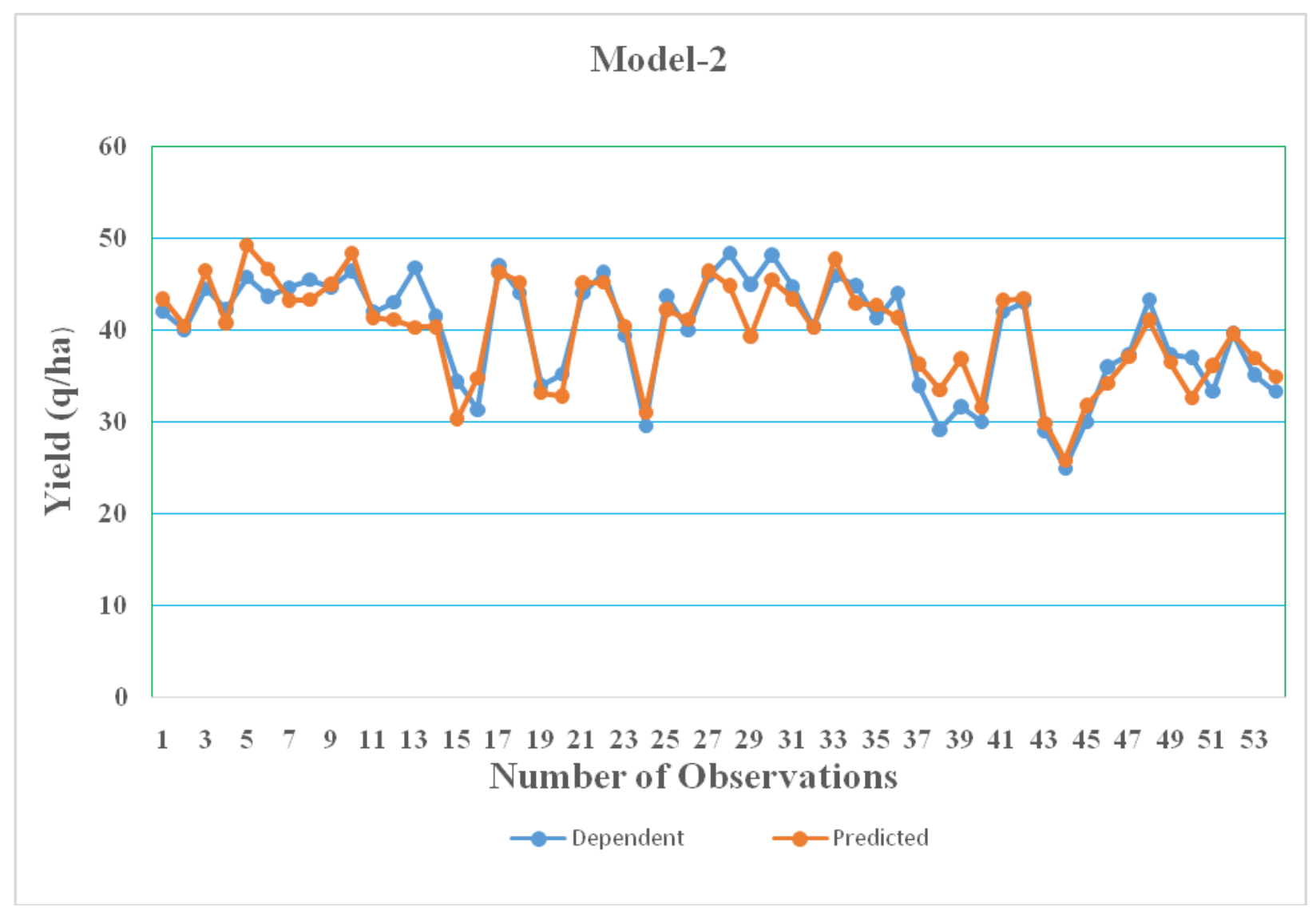

\section{References}

Anonymous (2018). Statistical data on area and production of paddy crop in India. F.A.O http://fao.org/faostat/en/\#data/QC

Anonymous (2018). Statistical data on area and production of paddy crop during season 2016-17. Directorate of Economics and Statistics, Government of Bihar.

Deep, C. K. Kumar, M. and Kumar, S. (2018). Yield estimation of rice (Oryzasativa L.) in Katihar district of Bihar. Advance in Bioresearch, 9 (2), 5560.

Draper, N. R. and Smith, H. (1966). Application of regression analysis. John Wiley and Sons, New York, $3^{\text {rd }}$ edition, 327-347.
Kumar, M. Singh, M. M. Kumar, S. (2017). Pre-harvest forecasting of rice yield using biometrical characters along with farmer's appraisal in Muzaffarpur district of Bihar. International Journal of Pure \& Applied Bioscience, 5 (5), 1553-155.

Nath, B., Singh, S.N. and Rai, G. (2018).Preharvest forecast of rice yield for Bhagalpur district in Bihar. Journal of Pharmacognosy and Phytochemistry, 7 (6), 2342-2345.

Pandey, K. K. Rai, V. N. Sisodia. B. V. S. Bharti, A. K. Gairola, K. C. (2013). Preharvest forecast models based on weather variables and weather indices for eastern U.P. Advance in Bioresearch, 4 (2), 118122.

Vogel, F. Bange, G. (1999). Understanding crop statistics. Retrivewed from https: // www.usda.gov/nassinfo/pub 1554.htm. 


\section{How to cite this article:}

Ravi Ranjan Kumar, S.N. Singh, Kiran Kumari and Bhola Nath. 2019. Yield Estimation of Rice Crop at Pre-Harvest Stage Using Regression Based Statistical Model for Arwal District, Bihar, India. Int.J.Curr.Microbiol.App.Sci. 8(08): 2491-2500.

doi: https://doi.org/10.20546/ijcmas.2019.808.290 